University of Nebraska - Lincoln

DigitalCommons@University of Nebraska - Lincoln

\title{
Mercury concentrations in fish from a Sierra Nevada foothill reservoir located downstream from historic gold-mining operations
}

\author{
Michael K. Saiki \\ U.S. Geological Survey, michael_saiki@usgs.gov \\ Barbara A. Martin \\ U.S. Geological Survey, Barbara_ann_martin@usgs.gov \\ Thomas W. May \\ U.S. Geological Survey \\ Charles N. Alpers \\ U.S. Geological Survey
}

Follow this and additional works at: https://digitalcommons.unl.edu/usgsstaffpub

Part of the Earth Sciences Commons

Saiki, Michael K.; Martin, Barbara A.; May, Thomas W.; and Alpers, Charles N., "Mercury concentrations in fish from a Sierra Nevada foothill reservoir located downstream from historic gold-mining operations" (2010). USGS Staff -- Published Research. 477.

https://digitalcommons.unl.edu/usgsstaffpub/477

This Article is brought to you for free and open access by the US Geological Survey at DigitalCommons@University of Nebraska - Lincoln. It has been accepted for inclusion in USGS Staff -- Published Research by an authorized administrator of DigitalCommons@University of Nebraska - Lincoln. 


\title{
Mercury concentrations in fish from a Sierra Nevada foothill reservoir located downstream from historic gold-mining operations
}

\author{
Michael K. Saiki • Barbara A. Martin • \\ Thomas W. May • Charles N. Alpers
}

Received: 17 October 2008 / Accepted: 5 February 2009 / Published online: 13 March 2009

(C) Springer Science + Business Media B.V. 2009

\begin{abstract}
This study examined mercury concentrations in whole fish from Camp Far West Reservoir, an 830-ha reservoir in northern California, USA, located downstream from lands mined for gold during and following the Gold Rush of 1848-1864. Total mercury (reported as dry weight concentrations) was highest in spotted bass (mean, $0.93 \mu \mathrm{g} / \mathrm{g}$; range, $0.16-4.41 \mu \mathrm{g} / \mathrm{g}$ ) and lower in bluegill (mean, $0.45 \mu \mathrm{g} / \mathrm{g}$; range, $0.22-$ $1.96 \mu \mathrm{g} / \mathrm{g})$ and threadfin shad $(0.44 \mu \mathrm{g} / \mathrm{g}$; range, $0.21-1.34 \mu \mathrm{g} / \mathrm{g})$. Spatial patterns for mercury in fish indicated high concentrations upstream in the Bear River arm and generally lower concentrations elsewhere, including downstream near the dam. These findings coincided with patterns exhibited by methylmercury in water and sediment, and suggested that mercury-laden inflows
\end{abstract}

M. K. Saiki $(\varangle)$ · B. A. Martin

U.S. Geological Survey, Western Fisheries Research

Center-Dixon Duty Station, 6924 Tremont Road,

Dixon, CA 95620, USA

e-mail: michael_saiki@usgs.gov

T. W. May

U.S. Geological Survey, Columbia Environmental

Research Center, 4200 New Haven Road,

Columbia, MO 65201, USA

C. N. Alpers

U.S. Geological Survey, California Water Science

Center, 6000 J Street, Sacramento, CA 95819, USA from the Bear River were largely responsible for contaminating the reservoir ecosystem. Maximum concentrations of mercury in all three fish species, but especially bass, were high enough to warrant concern about toxic effects in fish and consumers of fish.

Keywords Spotted bass • Bluegill •

Threadfin shad • Mercury • Camp Far West

Reservoir • Bear River • California

\section{Introduction}

Mercury contamination from gold mining operations dating back to the California Gold Rush of 1848-1864 is believed to be widespread in many rivers, lakes, and reservoirs on the western slopes of the Sierra Nevada (Alpers et al. 2005). Miners used elemental mercury (quicksilver) to recover gold from placer (alluvial) mines, which used hydraulic, drift, and dredging methods, and from hardrock (lode) mines. At hydraulic mining operations, which began in 1852 and peaked in 1880 (Craig and Rimstidt 1998), placer ores were eroded with monitors (water cannons) and the resulting slurry was directed through sluices and drainage tunnels where the gold particles were combined with liquid mercury to form gold-mercury amalgam. Bowie (1905) estimated that $10-30 \%$ of the mercury used in this process 
was lost each season, resulting in highly contaminated sediments downstream from the mines. According to Alpers et al. (2005), the annual loss of mercury from a typical sluice was likely several hundred kilograms during the operating season or roughly $1,400-4,000$ metric tons statewide. Although mercury was used in drift mining operations, in dredging operations, and at hardrock mines, which grew in importance after hydraulic mining came under control of the California Debris Commission in 1893 and placer deposits were exhausted (Craig and Rimstidt 1998), the amounts lost to the environment by these sources have not been estimated.

Although mercury was used throughout the northwestern Sierra Nevada, highest average concentrations measured in fish tissues occur in the Bear River and South Yuba River watersheds (Slotton et al. 1997). Judging from limited sampling of aquatic biota mostly above and below selected foothill reservoirs, the reservoirs seemingly serve as traps for both sediment-associated inorganic mercury and biologically available mercury (Slotton et al. 1997). May et al. (2000) reported that mercury concentrations were highest in upper-trophic-level predators (largemouth bass, Micropterus salmoides; smallmouth bass, M. dolomieui; and spotted bass, M. punctatus) from Camp Far West Reservoir and Lake Combie on the Bear River and Lake Englebright on the South Yuba River, with lower concentrations occurring in benthic omnivores (channel catfish, Ictalurus punctatus) and intermediate-trophiclevel predators (bluegill, Lepomis macrochirus; green sunfish, L. cyanellus; and black crappie, Pomoxis nigromaculatus). Moreover, within Camp Far West Reservoir, 14 spotted bass measuring 315-444 mm total length (TL) contained $0.58-1.5 \mu \mathrm{g} \mathrm{Hg} / \mathrm{g}$ (wet weight basis) in skinless fillets (May et al. 2000). In addition, one largemouth bass measuring $387 \mathrm{~mm}$ TL contained $0.81 \mu \mathrm{g} \mathrm{Hg} / \mathrm{g}$, three channel catfish measuring 437-479 mm TL contained $0.51-0.75 \mu \mathrm{g} \mathrm{Hg} / \mathrm{g}$, and three bluegill measuring 159-175 mm TL contained $0.22-0.34 \mu \mathrm{g} \mathrm{Hg} / \mathrm{g}$, all in skinless fillets (May et al. 2000).

Our study was intended to verify the preliminary findings of May et al. (2000) and better understand the extent and severity of mercury contamination in fish from Camp Far West Reservoir. Specific objectives were as follows: (1) determine if mercury concentrations varied spatially and temporally in selected fish species and (2) determine if mercury concentrations exceeded toxic threshold levels or related criteria for piscivorous fish and wildlife, and human consumers. The results were also intended to contribute towards a multidisciplinary federal investigation of mercury uptake and cycling within the reservoir, and help to identify mercury "hot spots" in the Bear-Yuba river watersheds for possible future remedial action (e.g., Kuwabara et al. 2003; Alpers et al. 2008; Stewart et al. 2008).

\section{Study area and methods}

Camp Far West Reservoir is an 830-ha reservoir located about $52 \mathrm{~km}$ north of Sacramento and $31 \mathrm{~km}$ southeast of Yuba City in Nevada, Placer, and Yuba counties, California (Fig. 1). The reservoir, which was constructed in 1963, is used mostly for storage of irrigation water by the South Sutter Water District (http://cdec.water.ca. gov/cgi-progs/damMeta?dam_id=202, accessed 30 January 2009). Inflow into Camp Far West Reservoir originates from a $741 \mathrm{~km}^{2}$ drainage basin, mostly from the Bear River with smaller inflows from Rock Creek and other sources. Surface-water characteristics measured at monthly or bi-monthly intervals from May 2002 to August 2003 varied as follows (values are minimamaxima): temperature, $7.3-28.9^{\circ} \mathrm{C}$; dissolved oxygen, 4.5-12.3 mg/L; pH, 6.6-8.5; specific conductance, 0.02-0.69 $\mu \mathrm{mhos} / \mathrm{cm} @ 25^{\circ} \mathrm{C}$; and turbidity, 0-656 nephelometric turbidity units (NTUs; turbidities >90 NTUs were measured only during a period of extreme reservoir drawdown in October 2002; M.K. Saiki, unpublished data).

The primary source of mercury to Camp Far West Reservoir is suspected to be transport of contaminated sediments from upstream reaches of the Bear River, especially during high-flow events (Kuwabara et al. 2003; Alpers et al. 2008). Historically, hundreds of gold mining operations occurred in the Bear River watershed upstream 
Fig. 1 Map of the study area

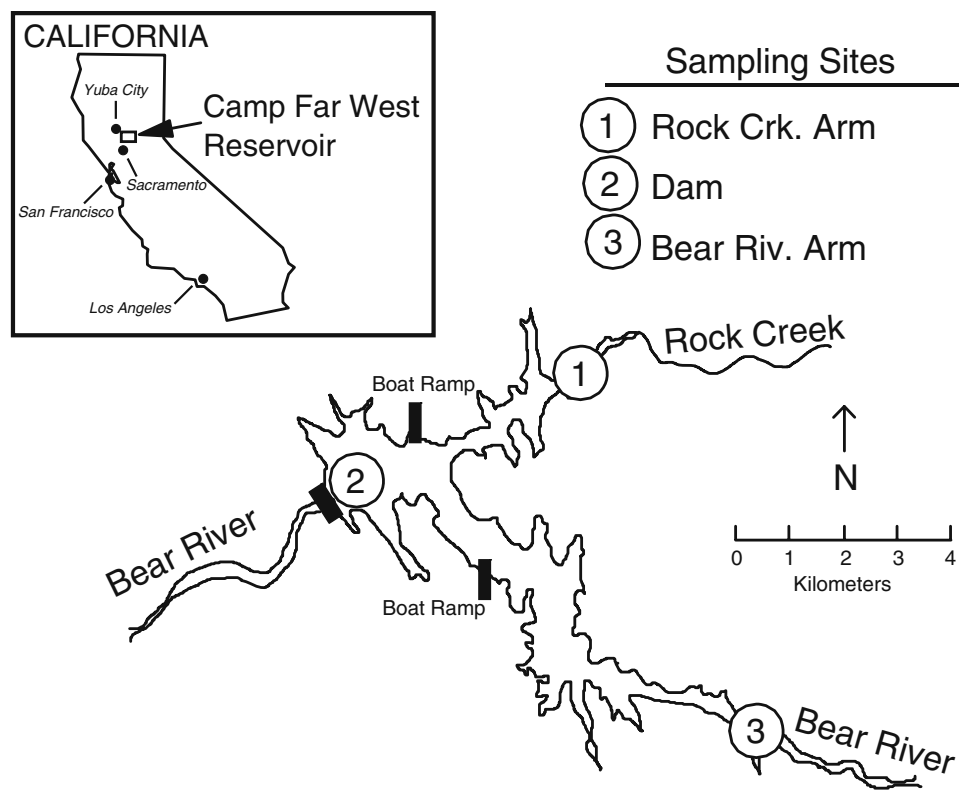

from the reservoir, each contributing to mercury loss during the gold-recovery process. Although data for the Rock Creek watershed are not available, its relatively small size was sufficient to support only a few gold-mining operations, probably leading to much lower inputs of mercury into the reservoir.

Fish collections

Spotted bass, bluegill, and threadfin shad (Dorosoma petenense) were sampled from Camp Far West Reservoir at three localities as follows: the Bear River arm, the Rock Creek arm, and the lower reservoir adjacent to the dam (Fig. 1). Sampling efforts focused on shallow shoreline areas of the reservoir where fish were thought to be most numerous. All sampling occurred during August 2002 and August 2003.

Fish were collected with a boat-mounted electroshocker. Sampling effort was not recorded because the goal was to fulfill specified quotas (either numbers of individuals or total biomass) of fish.

Captured fish were measured for TL and weight, then individually wrapped and bagged in plastic and chilled on wet ice. Within $12 \mathrm{~h}$ after returning from the field, the gastrointestinal tracts (esophagus to pyloric sphincter; however, only esophagus in threadfin shad) were opened by dissection to remove gut contents (food items), then most fish samples were rewrapped and bagged in plastic, and frozen $\left(-10^{\circ} \mathrm{C}\right)$. Gut contents were removed to reduce this potential source of variation in whole-fish mercury measurements and to characterize the forage items consumed by the fishes (fish gut contents are reported by Stewart et al. 2008). Bluegill less than $53 \mathrm{~mm}$ TL and threadfin shad less than $60 \mathrm{~mm}$ TL were grouped into composite samples (two to four fish per composite) to yield sufficient biomass for determinations of mercury and other measurements (e.g., moisture content and stable isotope ratios; stable isotope ratios are reported by Stewart et al. 2008).

In 2002, 20 spotted bass and 15 bluegill were selected at random for dissection and removal of skinless and boneless fillets from both sides of each fish. After weighing, the fillets were wrapped and bagged in plastic, then frozen. The remaining carcass (including the dissected gastrointestinal tract) of each fish was weighed, then wrapped and bagged in plastic and frozen. Separate measurements of mercury in fish fillets and their carcasses were used to generate predictive equations for converting mercury concentrations in whole fish to mercury concentrations in fillets. 
Determination of moisture content, total mercury, and methylmercury

All samples of fish were analyzed for moisture percentage and total mercury concentration. In addition, 15 whole-body samples of spotted bass and ten whole-body samples each of bluegill and threadfin shad were randomly selected from fish collected in 2002 for analysis of methylmercury concentration. Frozen samples were shipped overnight from the field station to analytical facilities at the Columbia Environmental Research Center (CERC), Columbia, Missouri, for further sample preparation and chemical analysis. Partially thawed fish samples were initially either minced with a titanium meat cleaver (samples weighing $<100 \mathrm{~g}$ ) or chopped with a meat cleaver and ground with a Hobart or Kitchenaid meat grinder (samples weighing $>100 \mathrm{~g}$ ), then lyophilized with a Virtis Genesis 35EL freeze dryer for moisture determination. After lyophilization, each dried fish sample was cryogenically ground to a fine powder with a Spex 6850 Freezer/Mill, then relyophilized overnight to remove residual moisture accumulated during cryogrinding. Dried samples were stored in glass vials in a desiccator while awaiting further processing.

Total mercury was determined with a direct mercury analyzer wherein a dried sample (usually $30-100 \mathrm{mg}$ ) was combusted in a stream of oxygen. All mercury in the sample was volatilized and trapped by amalgamation on a gold substrate, then thermally desorbed and quantified by atomic absorption spectrophotometry. The entire sequence was conducted with a Milestone DMA80 analyzer equipped with an automated sample carousel. For spotted bass and bluegill, total mercury was usually determined from a single analysis of each sample. For threadfin shad, total mercury was usually determined from an average of two analyses of each sample.

After analysis for total mercury, samples designated for methylmercury analysis were shipped from CERC to analytical facilities at Brooks Rand LLC, Seattle, Washington. Typically, $100 \mathrm{mg}$ of dried sample was digested by an alkaline $\mathrm{KOH} /$ ethanol procedure, with a final digestate volume of $2.5 \mathrm{~mL}$. Thirty microliters of this digestate was then subjected to aqueous phase ethylation, purge and trap, followed by GC separation, isothermal decomposition, and analysis by atomic fluorescence detection.

Quality control for both total mercury and methylmercury included blanks, replicates, precombustion or predigestion spikes, and tissue reference materials. An independent calibration verification standard for total mercury was analyzed at the beginning and end of each instrumental run to confirm the calibration status of the Milestone DMA-80 analyzer system. With one exception, the percent errors were well within $10 \%$ for 37 measurements of reference solutions used to verify instrument calibration during analysis of total mercury; the exceptional measurement was $11.6 \%$. Recoveries of reference solutions used for calibration during methylmercury determination varied from $79 \%$ to $113 \%$, and averaged $96 \%$. All analyses $(N=30)$ of National Research Council Canada dogfish muscle certified reference material (DORM-2) for total mercury were within the certified range of $4.64 \pm 0.26 \mu \mathrm{g} / \mathrm{g}$ dry weight (hereinafter, unless indicated otherwise, all mercury concentrations are reported as dry weights). This same material (dogfish muscle) analyzed for methylmercury $(N=10)$ exhibited recoveries varying from $72 \%$ to $120 \%$, and averaging $86 \%$. Method precision for total mercury, determined as percent relative standard deviation (\%RSD) from triplicate combustion, amalgamation, and analysis of fish tissue samples, was $\leq 10 \%$ except for one fish sample $(20 \%)$. Method precision for methylmercury in fish varied from $1.3 \%$ to $11 \%$ relative percent difference (\%RPD). Percent recovery of total mercury from pre-combustion tissue spikes $(N=56)$ varied from $77 \%$ to $117 \%$, and averaged $99 \%$. Recoveries of methylmercury from predigestion spikes varied from $78 \%$ to $105 \%$, and averaged $88 \%$. Total mercury blank equivalent concentrations were less than the method detection limits (MDLs) for 22 of 30 sample blocks or groups, but at or slightly above the MDLs for the remaining eight blocks. For total mercury, the MDLs varied from 0.0002 to $0.012 \mu \mathrm{g} / \mathrm{g}$, and averaged $0.0025 \mu \mathrm{g} / \mathrm{g}$, and the quantitation limits varied from 0.001 to $0.027 \mu \mathrm{g} / \mathrm{g}$, and averaged $0.010 \mu \mathrm{g} / \mathrm{g}$. For methylmercury, the MDLs averaged $1.5 \mathrm{ng} / \mathrm{g}$, and the quantitation limits averaged 

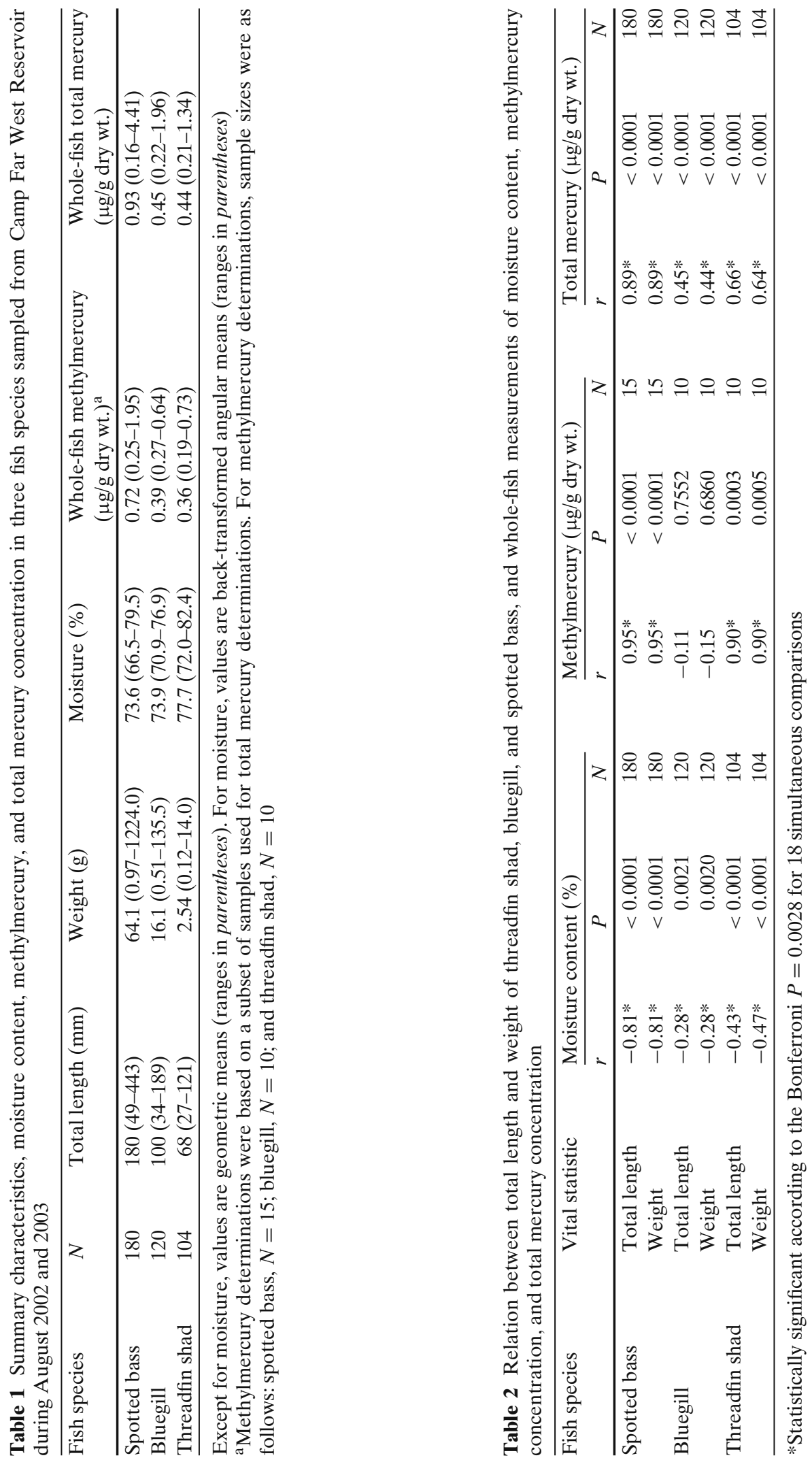
Table 3 Tests for homogeneity of slopes from regression equations that predict total mercury concentration as a function of total length in spotted bass, bluegill, and threadfin shad

\begin{tabular}{llrrrr}
\hline Taxa & Source & $d f$ & $M S$ & $F$ & \\
\hline Spotted bass & Interaction & 5 & 0.0162 & 0.97 & \\
& Error & 168 & 0.0167 & 3.4375 \\
Bluegill & Interaction & 5 & 0.0629 & 0.0176 & \\
& Error & 108 & 5 & 0.0275 & 3.17 \\
Threadfin shad & Interaction & 92 & 0.0087 & 0.0110 \\
& Error & & & \\
\hline
\end{tabular}

$4.2 \mathrm{ng} / \mathrm{g}$. Overall, these quality control results were within acceptable limits as specified by CERC.

\section{Data analysis}

Computerized databases were created as Excel spreadsheets. Raw data were analyzed by using SAS/STAT ${ }^{\circledR}$ and SAS/GRAPH® (SAS Institute Inc., Cary, NC, USA). Parametric techniquese.g., Pearson product-moment correlation, analysis of variance (ANOVA), and analysis of covariance (ANCOVA) - were used to summarize and interpret statistically significant relations among variables such as mercury body burdens and total length or weight of fish, and temporal-spatial variations. For ANCOVA, we used fish length as the covariate when comparing mercury concentrations because length does not decrease over time whereas weight sometimes does (Huckabee et al. 1979). To ensure normality, data were routinely subjected to standard transformations (e.g., angular transformation for moisture percentage; logarithmic transformation for length, weight, and mercury concentration). However, exponential functions were used when fitting curves to scatter plots of fish length and mercury concentrations because they yielded the largest coefficient of determination $\left(R^{2}\right)$ values. Prior to conducting ANCOVA, we tested the assumption that regression coefficients were similar (homogeneous) for the variables under comparison. If slopes were not homogeneous, we used a variation of ANCOVA referred to as "extra sums of squares." The "extra sums of squares" procedure measures the marginal reduction in the error sums of squares when one or several independent variables are added to the regression model, given that other independent variables are already in the model (Neter et al. 1990). Unless specified otherwise, the level of significance for all statistical tests was $P=0.05$.

\section{Results}

A total of 404 whole-fish samples were measured for moisture content and total mercury concentration during this study (Table 1). In addition, some whole-fish samples (15 spotted bass, ten bluegill, and ten threadfin shad) were also measured for methylmercury. The whole-fish results included 35 measurements (20 spotted bass and 15 bluegill) that were estimated from analysis of skinless fillets and their corresponding carcasses (whole fish less skinless fillets). Although moisture content was variable, threadfin shad generally exhibited the highest moisture content, with lower percentages measured in spotted bass and bluegill (Table 1). In addition, moisture content was inversely associated with fish size (TL and weight) in all three species (Table 2). On average, methylmercury and total mercury concentrations were highest in spotted bass and lower in bluegill and threadfin

Table 4 Results of analysis of covariance (ANCOVA), as $F$ values and significance levels, for total mercury concentrations (dry weight basis, adjusted for total length) in spotted bass collected from Camp Far West Reservoir during July 2002 and July $2003^{\mathrm{a}, \mathrm{b}}$

\begin{tabular}{lrcr}
\hline Source & $d f$ & $F$ & \multicolumn{1}{l}{$P$} \\
\hline Total length & 1 & 729.61 & $<0.0001$ \\
Site & 2 & 4.63 & 0.0110 \\
Year & 1 & 0.98 & 0.3225 \\
Site $\times$ year interaction & 2 & 0.91 & 0.4030 \\
Error MS & 173 & 0.0167 & \multicolumn{1}{l}{-} \\
\hline
\end{tabular}

${ }^{a}$ Before ANCOVA was conducted, regression equations were determined to exhibit homogeneous slopes (see Table 3)

${ }^{b}$ Bass used in total mercury determinations averaged $180 \mathrm{~mm} \mathrm{TL}$ 
shad (Table 1). Moreover, methylmercury and total mercury concentrations increased as TL and weight of spotted bass, bluegill (total mercury only), and threadfin shad increased (Table 2).

Methylmercury concentrations were strongly associated with total mercury concentrations in all three fish species (for spotted bass, $N=15, r=$ 0.99, $P<0.0001$; for bluegill, $N=10, r=0.88$, $P=0.0009$; for threadfin shad, $N=10, r=0.96$, $P<0.0001)$. Although linear regression equations describing the methylmercury:total mercury relations in each species exhibited similar slopes $\left(F_{2,29}=1.15, P=0.3321\right)$, the intercepts were significantly different $\left(F_{2,31}=5.31, P=0.0104\right)$. Moreover, the ratios of methylmercury to total mercury varied significantly among the three fish species $\left(F_{2,32}=4.16, P=0.0248\right)$. This variation was due to relatively high ratios measured in bluegill $(0.93,0.84-1.04$; values are geometric mean and $95 \%$ confidence interval) and lower ratios measured in threadfin shad $(0.78,0.71-$ $0.86)$. The methylmercury:total mercury ratios for spotted bass $(0.87,0.81-0.93)$ overlapped those of bluegill and threadfin shad.

Spatial and temporal variations in total mercury concentrations

The significant associations between total mercury concentration and fish size (TL and weight) of spotted bass, bluegill, and threadfin shad required

Table 5 Results of analysis of covariance (ANCOVA), as $F$ values and significance levels, for total mercury concentrations (dry weight basis, adjusted for total length) in use of ANCOVA to assess variations in mercury concentrations over the three sites and 2 years encompassed by this study. Prior to conducting ANCOVA, slopes of the mercury vs. total length relationship for each species were tested for homogeneity (Table 3). According to this assessment, the standard ANCOVA procedure was applicable only to spotted bass (i.e., we accepted the hypothesis that slopes were the same for each regression line). Slopes were not homogeneous for bluegill and threadfin shad, necessitating use of an "extra sums of squares" version of ANCOVA.

Total mercury concentrations in spotted bass varied among sites but not years (Table 4). Mercury concentrations (computed as least-squares means for spotted bass averaging $180 \mathrm{~mm}$ TL) were highest in the Bear River arm (0.991 $\mu \mathrm{g}$ $\mathrm{Hg} / \mathrm{g})$, slightly lower at the dam $(0.966 \mu \mathrm{g} \mathrm{Hg} / \mathrm{g}$, but the difference was not significantly different from the Bear River arm), and significantly lower in the Rock Creek arm $(0.850 \mu \mathrm{g} \mathrm{Hg} / \mathrm{g})$.

In bluegill, total mercury concentrations varied over both sites and years (Table 5). Mercury concentrations (computed as least-squares means for bluegill averaging $100 \mathrm{~mm}$ TL) were highest in the Bear River arm $(0.552 \mu \mathrm{g} \mathrm{Hg} / \mathrm{g})$, intermediate at the dam $(0.423 \mu \mathrm{g} \mathrm{Hg} / \mathrm{g})$, and lowest in the Rock Creek arm $(0.353 \mu \mathrm{g} \mathrm{Hg} / \mathrm{g})$, with each mean value differing significantly from the other two mean values. In addition, mean mercury concentrations were significantly higher in $2002(0.459 \mu \mathrm{g} \mathrm{Hg} / \mathrm{g})$ than in $2003(0.413 \mu \mathrm{g} \mathrm{Hg} / \mathrm{g})$.

bluegill and threadfin shad collected from Camp Far West Reservoir during July 2002 and July 2003

\begin{tabular}{llrrr}
\hline Taxa & Source & $d f$ & $F$ & \\
\hline Bluegill & Total length & 6 & 9.71 & $<$ \\
& Site & 8 & 6.13 & $<0.0001$ \\
& Year & 6 & 3.67 & 0.0001 \\
& Site $\times$ year interaction & 4 & 0.65 & 0.0024 \\
Threadfin shad & Error SS & 108 & 1.90 & - \\
& Total length & 6 & 48.42 & $<0.6250$ \\
& Site & 8 & 12.53 & $<0.0001$ \\
& Year & 6 & 14.32 & $<0.0001$ \\
& Site $\times$ year interaction & 4 & 4.48 & 0.0024 \\
\hline
\end{tabular}

Bluegill averaged $100 \mathrm{~mm}$ TL, whereas threadfin shad averaged $68 \mathrm{~mm}$ TL. The "extra sums of squares" procedure was used to compute ANCOVA results because regression equations exhibited unequal (non-homogeneous) slopes (see Table 3 ) 


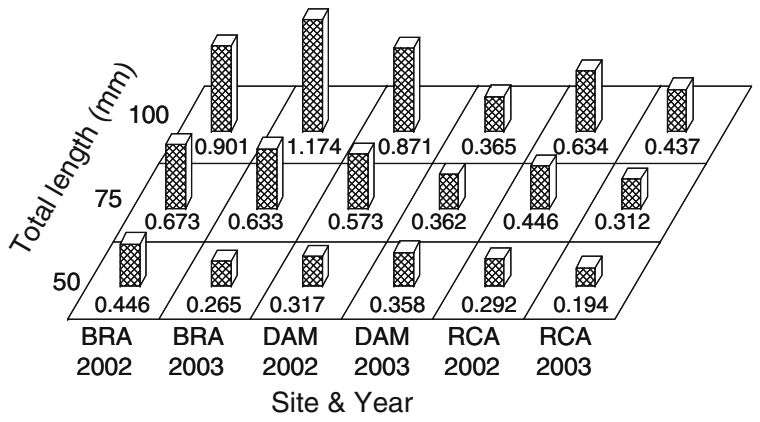

Fig. 2 Total mercury concentrations ( $\mu \mathrm{g} / \mathrm{g}$, dry weight basis) in small (50 mm TL), medium (75 mm TL), and large (100 mm TL) threadfin shad captured from the Bear River arm $(B R A)$, the Dam $(D A M)$, and the Rock Creek arm $(R C A)$ during August 2002 and August 2003. All values were computed as least-squares means

Total mercury concentrations in threadfin shad exhibited a significant site $\times$ year interaction (Table 5). Moreover, due to a significant total length $\times$ site $\times$ year interaction $\left(F_{2,92}=6.25, P=\right.$ 0.0029) in the full ANCOVA model, the site $x$ year interaction was not constant over the entire range of total length values (i.e., the relationship between mercury concentration and total length varied in shad captured from different sites and years). Thus, although mercury concentrations in all sizes of shad were generally highest in the Bear River arm, intermediate at the dam, and lowest in the Rock Creek arm, and higher in 2002 than in 2003, several exceptions were present. For example, in 2003, mercury concentrations were highest at the dam, intermediate in the Bear River arm, and lowest in the Rock Creek arm for small (50 mm TL) shad, and highest in the Bear River arm, intermediate in the Rock Creek arm, and lowest at the dam for large (100 mm TL) shad (Fig. 2). In addition, mercury concentrations were lower in 2002 than in 2003 for small shad at the dam and large shad in the Bear River arm (Fig. 2).

Total mercury concentrations in whole fish and fillets

To address human health concerns, 20 samples of spotted bass and 15 samples of bluegill were analyzed for total mercury as skinless fillets and carcasses (whole fish less the skinless fillets) to generate simple equations that predicted mercury concentrations in fillets when given whole-fish concentrations. For spotted bass, the relation
Fig. 3 Relation between total mercury concentrations in whole-fish samples and skinless fillets of spotted bass and bluegill sampled from Camp Far West Reservoir during August 2002




Fig. 4 Mercury concentrations in skinless fillets (estimated from whole-fish concentrations with equations given in Fig. 3) of spotted bass and bluegill from three localities $(B R$, Bear River arm; $D M$, dam; and $R C$, Rock Creek arm) in Camp Far West

Reservoir. Also shown are fish tissue concentration thresholds (horizontal dashed lines) associated with a national advisory for

noncommercial fish that recommended consumption limits of 4 meals/month $(0.12 \mu \mathrm{g}$ $\mathrm{Hg} / \mathrm{g}), 1 \mathrm{meal} / \mathrm{month}$ $(0.47 \mu \mathrm{g} \mathrm{Hg} / \mathrm{g})$, and 0 meals/month $(1.90 \mu \mathrm{g}$ $\mathrm{Hg} / \mathrm{g}$ )
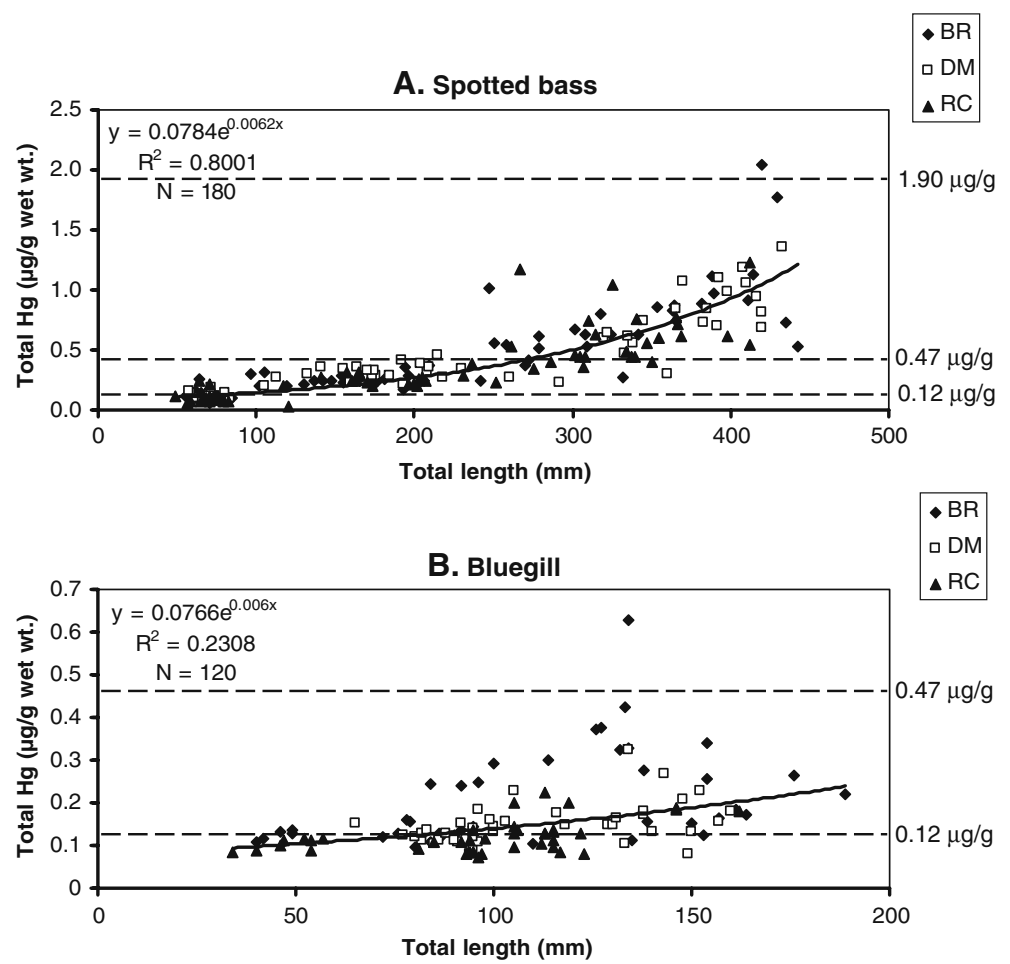

was described by the equation, $\log _{10}(\mathrm{FC})=$ $-0.48374+1.23099 \times \log _{10}(\mathrm{WC})$, where $\mathrm{FC}$ is fillet concentration (wet weight basis) and WC is whole-fish concentration (dry weight basis; see Fig. 3). For bluegill, the relation was described by the equation, $\log _{10}(\mathrm{FC})=-0.49105+0.99293 \times$ $\log _{10}$ (WC) (Fig. 3). According to these equations, the wet weight concentrations of mercury in fillets of spotted bass varied from 0.03 to $2.04 \mu \mathrm{g} / \mathrm{g}$, whereas those of bluegill varied from 0.07 to $0.63 \mu \mathrm{g} / \mathrm{g}$.

\section{Discussion}

Several investigators (Grieb et al. 1990; Bloom 1992; Wiener and Spry 1996) reported that approximately $95-99 \%$ of mercury in fish muscle tissues occurs as methylmercury, although at least one study (e.g., Mason et al. 2006) found methylmercury concentrations averaging only $28 \pm 14 \%$ in axial muscle of planktivorous white perch (Morone americana) and $65 \pm 22 \%$ in axial muscle of mostly piscivorous striped bass (Morone saxatilis) from tidal portions of Chesapeake Bay.
Data from our study indicated that methylmercury averaged $78-93 \%$ of total mercury measured in whole fish, with threadfin shad containing the lowest percentages and spotted bass and bluegill containing higher percentages. Goldstein et al. (1996) reported that total mercury concentrations were higher in muscle tissue than in the corresponding whole body for common carp (Cyprinus carpio) and channel catfish (Ictalurus punctatus). These results suggest that many non-muscle tissues (e.g., bones, scales, skin) present in samples of whole fish may contain disproportionately low concentrations of methylmercury. However, as noted by Goldstein et al. (1996), the ratio of methylmercury:total mercury in internal organs such as liver and the whole fish can vary among fish species, which might reflect physiological differences among different trophic groups.

Although fish are exposed to mercury from both water and food, bioaccumulation of mercury through the food chain plays a more important role in determining mercury burdens (Hall et al. 1997; Wiener et al. 2003). Fish probably assimilate $65-80 \%$ or more of the methylmercury present in the food they eat and eliminate methylmer- 
cury slowly relative to the rate of uptake (Wiener et al. 2003), resulting in a net increase in mercury burdens. This is one reason that mercury concentrations typically increase with size and age of the organism (Lange et al. 1993, 1994; Wiener et al. 2003). In Camp Far West Reservoir, mercury concentrations in spotted bass, bluegill, and threadfin shad also increased with TL and weight (Table 2; also Fig. 4).

Another reason that mercury concentrations often increase as fish get larger (older) is due to ontogenetic shifts in diet, especially in predatory species that initially feed on small lower-trophiclevel invertebrates as larvae and juveniles, but switch to large higher-trophic-level fish as subadults and adults. For example, MacCrimmon et al. (1983) observed increased rates of mercury accumulation in lake trout (Salvelinus namaycush) when the young switched from a diet of invertebrates to forage fish. Wren and MacCrimmon (1986) also observed that piscivorous fish had higher concentrations of mercury than prey fish of comparable age. In Camp Far West Reservoir, top-level predators such as spotted bass had higher concentrations of mercury than did lower-trophic-level insectivores and planktivores such as bluegill and threadfin shad (Table 1). Moreover, smaller (younger) bass, which generally feed on zooplankton and small insects, contained lower concentrations of mercury than did larger (older) bass that feed primarily on large-bodied invertebrates (e.g., crayfish) and forage fish (Stewart et al. 2008). By comparison, mercury concentrations in bluegill and threadfin shad were weakly correlated with body size possibly because juveniles and adults of these species tend to forage on similar foods (e.g., phytoplankton, vascular plants, zooplankton, immature aquatic insects, and other benthic invertebrates; Stewart et al. 2008). Unlike adult spotted bass, bluegill and threadfin shad are seldom piscivorous.

The spatial patterns observed for mercury in spotted bass and bluegill, and to a lesser extent in threadfin shad, indicated highest concentrations in the Bear River arm of Camp Far West Reservoir, followed by the dam, and lastly by the Rock Creek arm. These patterns were consistent with methylmercury concentrations measured in water samples filtered through quartz fiber filters (pore size, $0.7 \mu \mathrm{m}$ ) on as many as eight occasions during 2001-2003, wherein the Bear River arm contained $<0.04-0.32 \mathrm{ng} / \mathrm{L}$, the dam contained $<0.04-0.06 \mathrm{ng} / \mathrm{L}$, and the Rock Creek arm contained $<0.04-0.04 \mathrm{ng} / \mathrm{L}$ (Alpers et al. 2008). Methylmercury concentrations in particulate matter extracted from the water samples also showed highest concentrations in the Bear River arm $(<0.029-0.39 \mathrm{ng} / \mathrm{L})$, followed by the dam $(<0.029$ $0.097 \mathrm{ng} / \mathrm{L})$, and lastly by the Rock Creek arm $(<0.029-0.051 \mathrm{ng} / \mathrm{L}$; Alpers et al. 2008). Although data were not available from the Rock Creek arm, methylmercury concentrations measured during 2001-2003 in sediment samples from the Bear River arm (1.37-7.73 ng/g dry weight) were higher than from the dam (0.61-0.93 ng/g dry weight; M. Marvin-DiPasquale, U.S. Geological Survey, Menlo Park, California, unpublished data).

Mercury burdens in centrarchids (i.e., spotted bass and bluegill) from our study, which are known to exhibit restricted home ranges or site fidelity (Ball 1947; Fish and Savitz 1983; Horton 2000), probably reflect local exposure conditions wherein the primary source of mercury contamination was associated with inflows from the Bear River. However, we could not explain the higher mercury concentrations measured in bluegill during August 2002 than during August 2003 because too few samples of water and sediment were collected to assess annual variations in environmental exposure. Mercury burdens in threadfin shad were characterized by complex spatial and temporal patterns suggestive of highly variable exposure to mercury, such as might occur if the fish showed little or no site fidelity, instead roaming extensively throughout the reservoir. This contention is supported by limited information from other reservoirs that indicate shad are a highly mobile schooling species with patchy spatial distributions influenced diurnally and seasonally by water quality conditions (e.g., temperature and dissolved oxygen) and possibly by predators and prey (Allen and DeVries 1993; Schael et al. 1995).

Several investigators have attempted to establish toxic thresholds of mercury for fish life. According to Niimi and Kissoon (1994), overt effects on fish growth and survival occur at 
relatively high concentrations of $10-20 \mu \mathrm{g} \mathrm{Hg} / \mathrm{g}$ wet weight (roughly 40-80 $\mu \mathrm{g} / \mathrm{g}$ dry weight, assuming $75 \%$ moisture) in whole fish, which is rarely encountered under natural conditions. Recently, however, Beckvar et al. (2005) evaluated several approaches for deriving protective (i.e., unlikely to have adverse effects) tissue residueeffect concentrations in fish by using published datasets, and determined that the tissue thresholdeffect level (t-TEL) approach best represented available data. According to Beckvar et al. (2005), a whole-fish mercury t-TEL of $0.2 \mu \mathrm{g} / \mathrm{g}$ wet weight (roughly $0.8 \mu \mathrm{g} / \mathrm{g}$ dry weight, assuming $75 \%$ moisture) based largely on sublethal endpoints such as growth, reproduction, development, and behavior should protect juvenile and adult fish. During our study, total mercury concentrations exceeding $0.8 \mu \mathrm{g} / \mathrm{g}$ occurred in $60 \%$ (108 of 180 ) of spotted bass, $11 \%$ (13 of 120) of bluegill, and $11 \%$ (11 of 104) of threadfin shad, raising the possibility that some fish from Camp Far West Reservoir might contain sufficiently elevated body burdens of mercury to experience adverse ecotoxicological effects. Laboratory studies indicate that sublethal effects of mercury toxicity in fish can include suppression of sex hormones, altered reproductive behavior, and impaired reproduction, along with maternal transfer of potentially toxic doses of mercury to fish embryos during oogenesis (Scheuhammer et al. 2007).

Toxic thresholds for mercury in diets of piscivorous birds and mammals have been proposed by several investigators. For example, the common loon (Gavia immer), which can occur in northern California during winter months (see http://www. mbr-pwrc.usgs.gov/bbs/htm96/cbc622/ra0070.html, accessed 30 January 2009), is especially susceptible to mercury toxicity. Adult loon diets containing $>0.3 \mu \mathrm{g} \mathrm{MeHg} / \mathrm{g}$ wet weight (about $1.2 \mu \mathrm{g} / \mathrm{g}$ dry weight, assuming $75 \%$ moisture) were associated with severely reduced reproductive success, mainly due to decreased egg laying and territorial fidelity in breeding adults (Barr 1986). Although loon chicks did not exhibit overt signs of toxicosis or significant reductions in growth or food-consumption rates when fed daily from hatch through day 105 on fish diets containing as much as $1.2 \mu \mathrm{g} / \mathrm{g}$ wet weight as methylmercury chloride (Kenow et al. 2003), there was evidence of reduced immune response and histological changes (central nervous system demyelination) in chicks receiving $0.4 \mu \mathrm{g} \mathrm{MeHg} / \mathrm{g}$ wet weight, or roughly $1.6 \mu \mathrm{g} / \mathrm{g}$ dry weight (assumes $75 \%$ moisture; Meyer 2006, cited by Scheuhammer et al. 2007). In mammals such as American mink (Mustela vison) and river otter (Lutra canadensis), which are permanent residents of northern California (for mink distribution in California, see http://www.sibr.com/mammals/M158.html, accessed 30 January 2009; for otter distribution, see http://www.sibr.com/mammals/M163.html, accessed 30 January 2009), consumption of fish containing methylmercury $\geq 1 \mu \mathrm{g} / \mathrm{g}$ wet weight (about $4 \mu \mathrm{g} / \mathrm{g}$ dry weight, assuming $75 \%$ moisture) has been shown to cause neurotoxicity and death (Wiener et al. 2003 and references therein). These toxic concentrations of mercury were equaled or exceeded by at least some whole-body samples of spotted bass and bluegill (piscivorous birds only), but not threadfin shad, during our study. However, to our knowledge, no one has attempted to document adverse ecotoxicological responses in piscivorous birds and mammals from the Camp Far West Reservoir vicinity.

In 2004, a national advisory for human consumption of mercury-tainted noncommercial fish was jointly issued by the U.S. Food and Drug Administration (FDA) and the U.S. Environmental Protection Agency (EPA; US DHHS and US EPA 2004; for details on how the advisory was developed, see US EPA 2004). This advisory updated an earlier action level of $1.0 \mu \mathrm{g} / \mathrm{g}$ wet weight for methylmercury in fish muscle tissue that the FDA used to regulate the sale of commercially caught fish (US FDA 1994), and a fish tissue criterion of $0.3 \mu \mathrm{g}$ methylmercury/g wet weight established by the EPA to avoid undesirable neurological abnormalities in human infants exposed in utero when pregnant women consume mercurycontaminated foods (US EPA 2001). The updated advisory included several thresholds for mercury concentrations linked to risk-based consumption limits of fish. For comparison with our study, we selected three arbitrary threshold concentrations $(0.12,0.47$, and $1.90 \mu \mathrm{g} / \mathrm{g}$ wet weight) corresponding to 4,1 , and 0 meals of 227 -g fish servings per 
month. In other words, if fish contained $0.12 \mu \mathrm{g}$ $\mathrm{Hg} / \mathrm{g}$, no more than four meals per month should be consumed to ensure a safe level of mercury exposure. However, if fish contained over $1.90 \mu \mathrm{g}$ $\mathrm{Hg} / \mathrm{g}$, none should be consumed.

In Camp Far West Reservoir, spotted bass measuring $69 \mathrm{~mm}$ TL were predicted to contain $0.12 \mu \mathrm{g} \mathrm{Hg} / \mathrm{g}$ wet weight in their fillets, whereas bass measuring $289 \mathrm{~mm}$ TL were predicted to contain $0.47 \mu \mathrm{g} \mathrm{Hg} / \mathrm{g}$ wet weight (Fig. 4). Moreover, the largest bass captured during our study (443 mm TL) was predicted to contain $1.22 \mu \mathrm{g}$ $\mathrm{Hg} / \mathrm{g}$ wet weight in its fillets. However, at least four smaller fish exceeded this concentration, with one fish (a bass measuring $420 \mathrm{~mm}$ TL) containing as much as $2.04 \mu \mathrm{g} \mathrm{Hg} / \mathrm{g}$ wet weight. By comparison, bluegill measuring $75 \mathrm{~mm}$ TL were expected to contain $0.12 \mu \mathrm{g} / \mathrm{g}$ wet weight in their fillets, with the largest fish (189 mm TL) predicted to contain $0.24 \mu \mathrm{g} / \mathrm{g}$ wet weight (Fig. 4). However, fillet concentrations in at least 15 bluegill exceeded $0.24 \mu \mathrm{g} / \mathrm{g}$ wet weight, with a fish measuring $134 \mathrm{~mm}$ TL exhibiting a maximum concentration of $0.63 \mu \mathrm{g} / \mathrm{g}$ wet weight. Nevertheless, our findings indicate that fish (especially bass) from Camp Far West Reservoir exhibit sufficiently elevated concentrations of mercury in their fillets to warrant fish consumption guidelines available in human health advisories. Mercury concentrations in threadfin shad were excluded from similar comparisons because this species is not routinely consumed by humans.

In conclusion, our results indicated that mercury concentrations in spotted bass, bluegill, and threadfin shad varied according to fish size, with higher concentrations occurring in larger (older) fish. Moreover, most of the mercury in whole-fish samples was present as methylmercury. Although variation was present, mercury concentrations were generally highest in fish sampled from the Bear River arm and lower elsewhere, possibly because this portion of the reservoir intercepted most of the bioavailable mercury transported from former gold-mining sites located upstream in the Bear River, along with trapping much of the sediment-associated inorganic load. Maximum concentrations of mercury measured in whole-fish samples of bass, but not bluegill or shad, fell within the lower ranges of concentra- tions that other investigators proposed as being potentially toxic to fish and to at least some fisheating birds or mammals. Estimates of mercury concentrations in fillets of bass and bluegill were sufficiently elevated to warrant fish consumption guidelines available in a national human-health advisory. Collectively, these results confirmed the earlier findings of May et al. (2000) that fish from Camp Far West Reservoir were contaminated with undesirably high concentrations of mercury. Largely in response to data from May et al. (2000), the California Office of Environmental Health Hazard Assessment recommended no consumption of "black bass" by women of childbearing age and children 17 years and younger, and a maximum of two meals per month of "black bass" by women beyond childbearing years and men (Klasing and Brodberg 2003). These recommendations are also given in the 2008-2009 Freshwater Sport Fishing Regulations for the State of California (http://www.dfg.ca.gov/ regulations/08-09-inland-fish-regs.pdf, accessed 30 January 2009).

Acknowledgements We thank M.A. Farhina, P.C. Gerrity, M.E. Langsner, F.H. Mejia, and A.A. Story for assisting with fish collections, processing samples, or assisting with data entry and other technical support, M.J. Walther and W.G. Brumbaugh for assisting with mercury determinations and J.W. Arms for assisting with moisture determinations in fish samples, and J.L. Yee for providing statistical advice. We especially thank the California State Water Resources Control Board for funding this work through Customer Agreement No. 00-218-250-0 with the U.S. Geological Survey, California Water Science Center. Any use of trade names is for descriptive purposes only and does not imply endorsement by the U.S. Government.

\section{References}

Allen, M. S., \& DeVries, D. R. (1993). Spatial and temporal heterogeneity of larval shad in a large impoundment. Transactions of the American Fisheries Society, 122, 1070-1079. doi:10.1577/15488659(1993) $122<1070:$ SATHOL $>2.3$. CO;2.

Alpers, C. N., Hunerlach, M. P., May, J. T., \& Hothem, R. L. (2005). Mercury contamination from historic gold mining in California. U.S. Geological Survey Fact Sheet 2005-3014 Version 1.1, Sacramento, CA, USA.

Alpers, C. N., Stewart, A. R., Saiki, M. K., MarvinDiPasquale, M. C., Topping, B. R., Rider, K. M., et al. (2008). Environmental factors affecting mercury 
in Camp Far West Reservoir, California, 2001-03. U.S. Geological Survey Scientific Investigations Report 2006-5008, Sacramento, CA, USA.

Ball, R. C. (1947). A tagging experiment on the fish population of Third Sister Lake, Michigan. Transactions of the American Fisheries Society, 74, 360369. doi:10.1577/1548-8659(1944)74[360:ATEOTF]2. $0 . \mathrm{CO} ; 2$.

Barr, J. F. (1986). Population dynamics of the common loon (Gavia immer) associated with mercurycontaminated waters in northwestern Ontario. Canadian Wildlife Service Occasional Paper No. 56, Ottawa, Canada.

Beckvar, N., Dillon, T. M., \& Read, L. B. (2005). Approaches for linking whole-body fish tissue residues of mercury or DDT to biological effects thresholds. Environmental Toxicology and Chemistry, 24, 20942105. doi:10.1897/04-284R.1.

Bloom, N. S. (1992). On the chemical form of mercury in edible fish and marine invertebrate tissue. Canadian Journal of Fisheries and Aquatic Sciences, 49, 10101017. doi:10.1139/f92-113.

Bowie, A. J. (1905). A practical treatise on hydraulic mining in California. New York: Van Nostrand.

Craig, J. R., \& Rimstidt, J. D. (1998). Gold production history of the United States. Ore Geology Reviews, 13, 407-464. doi:10.1016/S0169-1368(98)00009-2.

Fish, P. A., \& Savitz, J. (1983). Variations in home ranges of largemouth bass, yellow perch, bluegills, and pumpkinseeds in an Illinois lake. Transactions of the American Fisheries Society, 112, 147-153. doi:10.1577/ 1548-8659(1983)112<147:VIHROL > 2.0.CO;2.

Goldstein, R. M., Brigham, M. E., \& Stauffer, J. C. (1996). Comparison of mercury concentrations in liver, muscle, whole bodies, and composites of fish from the Red River of the North. Canadian Journal of Fisheries and Aquatic Sciences, 53, 244-252. doi:10. 1139/cjfas-53-2-244.

Grieb, T. M., Driscoll, C. T., Gloss, S. P., Schofield, C. L., Bowie, G. L., \& Porcella, D. B. (1990). Factors affecting mercury accumulation in fish in the upper Michigan peninsula. Environmental Toxicology and Chemistry, 9, 919-930. doi:10.1897/15528618(1990)9[919:FAMAIF]2.0.CO;2.

Hall, B. D., Bodaly, R. A., Fudge, R. J. P., Rudd, J. W. M., \& Rosenberg, D. M. (1997). Food as the dominant pathway of methylmercury uptake by fish. Water, Air, and Soil Pollution, 100, 13-24.

Horton, T. B. (2000). Habitat use and movement of spotted bass in Otter Creek, Kansas. Manhattan, KS, USA: M.S. Thesis, Kansas State University.

Huckabee, J. W., Elwood, J. W., \& Hildebrand, S. C. (1979). Accumulation of mercury in freshwater biota. In J. O. Nriagu (Ed.), The biogeochemistry of mercury in the environment (pp. 277-302). Amsterdam: Elsevier.

Kenow, K. P., Gutreuter, S., Hines, R. K., Meyer, M. W., Fournier, F., \& Karasov, W. H. (2003). Effects of methyl mercury exposure on the growth of juvenile common loons. Ecotoxicology (London, England), 12, 171-182. doi:10.1023/A:1022598525891.
Klasing, S., \& Brodberg, R. (2003). Evaluation of potential health effects of eating fish from selected water bodies in the northern Sierra Nevada foothills (Nevada, Placer, and Yuba counties): Guidelines for sport fish consumption. Technical report, Pesticide and Environmental Toxicology Section, Office of Environmental Health Hazard Assessment, California Environmental Protection Agency, Oakland, CA, USA, 48 p.

Kuwabara, J. S., Alpers, C. N., Marvin-DiPasquale, M., Topping, B. R., Carter, J. L., Stewart, A. R., et al. (2003). Sediment-water interactions affecting dissolved- mercury distributions in Camp Far West Reservoir, California. U.S. Geological Survey Water Resources Investigation Report 03-4140, Menlo Park, CA, USA.

Lange, T. R., Royals, H. E., \& Connor, L. L. (1993). Influence of water chemistry on mercury concentration in largemouth bass from Florida lakes. Transactions of the American Fisheries Society, 122, 74-84. doi:10. 1577/1548-8659(1993)122<0074:IOWCOM>2.3.CO;2.

Lange, T. R., Royals, H. E., \& Connor, L. L. (1994). Mercury accumulation in largemouth bass (Micropterus salmoides) in a Florida lake. Archives of Environmental Contamination and Toxicology, 27, 466-471. doi:10.1007/BF00214837.

MacCrimmon, H. R., Wren, C. D., \& Gots, B. L. (1983). Mercury uptake by lake trout, Salvelinus namaycush, relative to age, growth, and diet in Tadenac Lake with comparative data from other Precambrian shield lakes. Canadian Journal of Fisheries and Aquatic Sciences, 40, 114-120. doi:10.1139/f83-020.

Mason, R. P., Heyes, D., \& Sveinsdottir, A. (2006). Methylmercury concentrations in fish from tidal waters of the Chesapeake Bay. Archives of Environmental Contamination and Toxicology, 51, 425-437. doi:10.1007/s00244-004-0230-x.

May, J. T., Hothem, R. L., Alpers, C. N., \& Law, M. A. (2000). Mercury bioaccumulation in fish in a region affected by historic gold mining: The South Yuba River, Deer Creek, and Bear River watersheds, California. U.S. Geological Survey Open-File Report 00-367, Sacramento, CA, USA.

Meyer, M. W. (2006). Evaluating the impact of multiple stressors on common loon population demographicsAn integrated laboratory and field approach. USEPA STAR Grant R82-9085, Final Report, July 31, 2006. Rhinelander, WI, USA.

Neter, J., Wasserman, W., \& Kutner, M. H. (1990). Applied linear statistical models: Regression analysis of variance, and experimental designs (3rd ed). Homeland: Richard D. Irwin.

Niimi, A. J., \& Kissoon, G. P. (1994). Evaluation of the critical body burden concept based on inorganic and organic mercury toxicity to rainbow trout (Oncorhynchus mykiss). Archives of Environmental Contamination and Toxicology, 26, 169-178. doi:10. 1007/BF00224801.

Schael, D. M., Rice, J. A., \& Degan, D. J. (1995). Spatial and temporal distribution of threadfin shad in a southeastern reservoir. Transactions of the 
American Fisheries Society, 124, 804-812. doi:10.1577/ 1548-8659(1995)124<0804:SATDOT > 2.3.CO;2.

Scheuhammer, A. M., Meyer, M. W., Sandheinrich, M. B., \& Murray, M. W. (2007). Effects of environmental methylmercury on the health of wild birds, mammals, and fish. Ambio, 36, 12-18. doi:10.1579/ 0044-7447(2007)36[12:EOEMOT]2.0.CO;2.

Slotton, D. G., Ayers, S. M., Reuter, J. E., \& Goldman, C. R. (1997). Gold mining impacts on food chain mercury in northwestern Sierra Nevada streams (1997 revision). Technical Report, Division of Environmental Studies, University of California-Davis, Davis, CA, USA, $71 \mathrm{p}$.

Stewart, A. R., Saiki, M. K., Kuwabara, J. S., Alpers, C. N., Marvin-DiPasquale, M., \& Krabbenhoft, D. P. (2008). Influence of plankton mercury dynamics and trophic pathways on mercury concentrations of top predator fish of a mining-impacted reservoir. Canadian Journal of Fisheries and Aquatic Sciences, 65, 23512366. doi:10.1139/F08-140.

US DHHS and US EPA (U.S. Department of Health and Human Services, and U.S. Environmental Protection Agency) (2004). What you need to know about mercury in fish and shellfish. U.S. Environmental Protection Agency, Washington, DC, USA, EPA-823-R-04-005, March 2004. http://www.cfsan.fda. gov/ dms/admehg3.html. Accessed 30 January 2009.

US EPA (U.S. Environmental Protection Agency) (2001). Water quality criterion for the protection of human health: Methyl mercury. Technical report, U.S. Environmental Protection Agency, Washington, DC, USA, EPA-823-R-01-001. http://www.epa.gov/waterscience/ criteria/methylmercury/. Accessed 30 January 2009.

US EPA (U.S. Environmental Protection Agency) (2004). Origin of the $1 \mathrm{meal} /$ week noncommercial fish consumption rate in national advisory for mercury. Technical memorandum, U.S. Environmental Protection Agency, Washington, DC, USA, March 11, 2004. http://www.epa.gov/waterscience/fish/advice/1-perweek.pdf. Accessed 30 January 2009.

US FDA (U.S. Food and Drug Administration) (1994). Mercury in fish: Cause for concern? FDA Consumer 28(7), unnumbered pages. http://www.fda.gov/fdac/ reprints/mercury.html. Accessed 30 January 2009.

Wiener, J. G., \& Spry, D. J. (1996). Toxicological significance of mercury in freshwater fish. In W. N. Beyer, G. H. Heinz, \& A. W. Redmon (Eds.), Environmental contaminants in wildlife-interpreting tissue concentrations (pp. 297-339). Boca Raton: Lewis.

Wiener, J. G., Krabbenhoft, D. P., Heinz, G. H., \& Scheuhammer, A. M. (2003). Ecotoxicology of mercury. In D. J. Hoffman, B. A. Rattner, G. A. Burton, and J. Cairns (Eds.), Handbook of ecotoxicology (2nd ed., pp. 409-463). Boca Raton: CRC.

Wren, C. D., \& MacCrimmon, H. R. (1986). Comparative bioaccumulation of mercury in two adjacent freshwater ecosystems. Water Research, 20, 763-769. doi:10. 1016/0043-1354(86)90101-6. 